\title{
GEOENVIRONMENTAL ANALYSIS OF OIL EXTRACTION ACTIVITIES IN URBAN AND RURAL ZONES OF SANTA ELENA PROVINCE, ECUADOR
}

\author{
GRICELDA HERRERA-FRANCO ${ }^{1}$, PAULO ESCANDÓN-PANCHANA ${ }^{1,2}$, KARLA ERAZO $^{3,4}$, \\ CARLOS MORA-FRANK ${ }^{1,4} \&$ EDGAR BERREZUETA ${ }^{5}$ \\ ${ }^{1}$ Universidad Estatal Península de Santa Elena, UPSE, Facultad de Ciencias de la Ingeniería, Ecuador. \\ ${ }^{2}$ ESPOL Polytechnic University, Escuela Superior Politécnica del Litoral, \\ Geo-Recursos y Aplicaciones GIGA, Ecuador. \\ ${ }^{3}$ Universidad de La Frontera, Departamento de Ciencias Químicas y Recursos Naturales, Temuco, Chile. \\ ${ }^{4}$ ESPOL Polytechnic University, Escuela Superior Politécnica del Litoral, ESPOL, Centro de Investigación y \\ Proyectos Aplicados a las Ciencias de la Tierra (CIPAT), Ecuador. \\ ${ }^{5}$ Instituto Geológico y Minero de España (IGME), Departamento de Infraestructura \\ Geocientífica y Servicios, Spain.
}

\begin{abstract}
From an environmental viewpoint, oil wells can be considered a potential source of pollution when improperly managed. The Santa Elena province (Ecuador), located on the Pacific coast, currently has a residual crude oil extraction compared to production generated in the Amazon region of the country. However, this activity in the coastal zone is very near to urban and rural populations. Therefore, a detailed influence analysis of these wells on the environment is necessary. This work aims to analyse, from a geoenvironmental perspective, the oil wells impact located in a pilot zone (urban and rural) of the oil field studied and, complementarily, to describe their incidence on the community and territory. The methodological process includes (i) oil wells compilation and inventory within the study zone and selection of a pilot zone; (ii) contaminating factors identification generated by the wells infrastructure (mechanical and territorial) and their current state of activity (production or abandoned); (iii) environmental impacts analysis generated through the development of a cause-effect matrix and, finally, the evaluation of a method and results found through a focus group technique. The results reflect a negative impact on the land cover and vegetative-animal environment in the vicinity of the wells, caused by the continuous release of gases, metallic oxidation and bituminous exhumation. The overall impacts interpretation compiled indicates that comprehensive action is needed at the wells to control and minimise them. The implementation of new environmental strategies through zoning can help to achieve adequate land-use planning, thus combining the safe and sustainable use of the resource with the development of other community activities (urbanisation, tourism, industry, agriculture and fishing) and environmental protection.
\end{abstract}

Keywords: extraction activities, geoenvironmental, land-use planning, oil wells, Santa Elena.

\section{INTRODUCTION}

Ecuador is an oil-producing country (approx. 530,000 barrels per day), and at the regional level, it is among the largest oil producers and exporters in the world [1]. This activity has a favourable influence on the country's gross domestic product (GDP) growth, generating economic and social development opportunities [2]. The balance of GDP is linked to the variation of oil prices, directly affecting the Ecuadorian economy [3]. In 2016 and 2020, the economy declined critically because of this factor, leading to industrial problems and labour intervention (internal and external) [4]. The Ecuadorian economy essentially involves petroleum production in the Amazon region (it has large proven and probable reserves) [5]. The extracted oil reserves mainly reach countries such as the United States, Panama, Chile, Peru and China [6]. However, the exportation of oil demands a series of industrial processes (e.g. exploration, drilling, production and transportation) [7]. These processes require strict control procedures since they cause environmental and population disturbances. 
Petroleum production is an essential source of Ecuador's economy, but its industrial factors harm the natural environment [8]. In addition, geoenvironmental protection of the megadiversity in the country's regions (coast (Costa), Andean highlands (Sierra), Amazon basin (Oriente) and the Galápagos Islands) is necessary [9], [10]. Ecuador's regions have geoenvironmental problems such as oil spills, gas flaring, toxic gas emissions, leaks, waste and heavy machinery handling. In Ecuador, anthropogenic activities lack environmental control and scarce technological updating [11]. An example of environmental problems was an accumulation of 29,000 barrels of oil spilt in the Amazon between 1994 and 2001 (without recovering 24\%) [12]. To counter this, there are government laws that prioritise the importance of environmental protection as indicated in the 'Hydrocarbons Law' proposed in 1978 (with a 2018 update) [13]: Art. 1 mentions that hydrocarbon deposits and accompanying substances located in onshore and offshore environments shall conform to the guidelines of sustainable development, protection and conservation of the environment; Art. 31 (paragraph $\mathrm{t}$ ), petroleum operations must be conducted based on laws and regulations for the protection of the environment and the security of the country. In addition, the state implements the 'Proyecto de Ley Orgánica de Ordenamiento Territorial, Uso y Gestión de Suelo' [14] which aims at: 'the rational and sustainable use of the territory's resources', 'the protection of the territory's natural and cultural heritage', and 'the regulation of interventions in the territory by proposing and implementing norms that guide the formulation and execution of public policies'.

The Amazon region of Ecuador has the most significant petroleum production. However, the coastal region has more than a hundred years of petroleum production, specifically in the Santa Elena province [15]. The province's oil was of great importance to Ecuador in the 20th century. The province focuses its production in the southern part, containing approximately 2,900 oil wells, managed by Pacifpetrol S.A. with an annual average of 360,000 barrels [16]. Studies determine that the producing rock in the south of the province is the Santo Tomas formation, has crude oil of lower density than that in the eastern region [17]. This variation in densities makes the province's crude oil important for blending with heavy crude oil [18]. The reserves in Santa Elena decrease annually, becoming less profitable to sustain the extraction, reconditioning, storage and transportation processes [19]. There are explorations to find new reserves in the province, but the results show little likelihood of maintaining production in this country's sector. Although there are few reserves, their extraction for more than 100 years has generated geoenvironmental alterations in the territory [20].

The companies in charge of oil extraction and exploitation, such as Pacifpetrol S.A. (production) [16] and EP Petroecuador (refining) [21], apply environmental controls in their processes. Pacifpetrol S.A. carries out continuous monitoring controls for economic profitability and environmental sustainability [22]. However, there are actions to consider in the operational management of wells, such as natural gas emissions and old wells in poor condition [20,23]. On the other hand, EP Petroecuador has an environmental system that prioritises safety and respect for nature. However, this model has not covered the totality of geoenvironmental problems, as its processes generate the emission of gases and toxic waste. These factors affect the environment and the health of all living beings [24].

In general, the companies in charge make efforts to solve the problems generated by industrial operations, although these do not reach their complete totality. In recent years, academic institutions have carried out theses and projects dealing with geoenvironmental assessment and protection of the territory. These studies address research on the health impact and environmental pollution due to oil wells [20], [25] and risk assessment and hydrocarbon saturation 
caused by the La Libertad Refinery (RLL) [26]. In addition, municipal entities make efforts to keep the environment free of pollution through strategic plans such as the Plan de Desarrollo y Ordenamiento Territorial (PDOT, acronym in Spanish). On the one hand, the PDOT of Santa Elena generates strategic policies to counteract environmental problems [27], such as 'plan, promote, execute and monitor the conservation and sustainable use of the natural heritage', and 'encourage the recovery of areas for productive purposes', 'license, control and monitor compliance with environmental regulations'. On the other hand, the canton of Salinas (Santa Paula area) mentions that it does not have the respective ordinances to control non-renewable resources (oil production) [28]. However, it has environmental regulations through ordinances found in the hydrocarbon laws of the Ecuadorian state (e.g. [13, 29]).

There are initiatives focused on the geoenvironmental conservation of the environment, such as the 'Peninsula Santa Elena Geopark project'. This initiative promotes the heritage and natural conservation of sites with geotourism potential [30]. The project aims to generate scientific and social content on the geoenvironmental status of the Santa Elena province. In this paper, we propose to analyse the polluting factors caused by oil activity in urban and rural pilot zones through the experience of experts in the area and thus define the geoenvironmental impacts produced. This study aims to analyse, from a geoenvironmental perspective, the geoenvironmental problems caused by oil wells in two pilot zones and the detailed description of alternatives to solve the problems in the community and territory.

\section{CASE STUDY}

The Santa Elena province is the most salient point (Fig. 1b and c) on the coast of Ecuador [31]. Its territorial extension is $3,690 \mathrm{~km}^{2}$. The north of the province has a mountainous territory of the Chongón-Colonche range, while the south has a semi-arid geological structure, with temperatures ranging from $17^{\circ} \mathrm{C}$ to $29^{\circ} \mathrm{C}$ [32]. The climatic behaviour has two seasons, summer (dry) and winter (rainy), affected by prolonged droughts in the extreme south, altering food

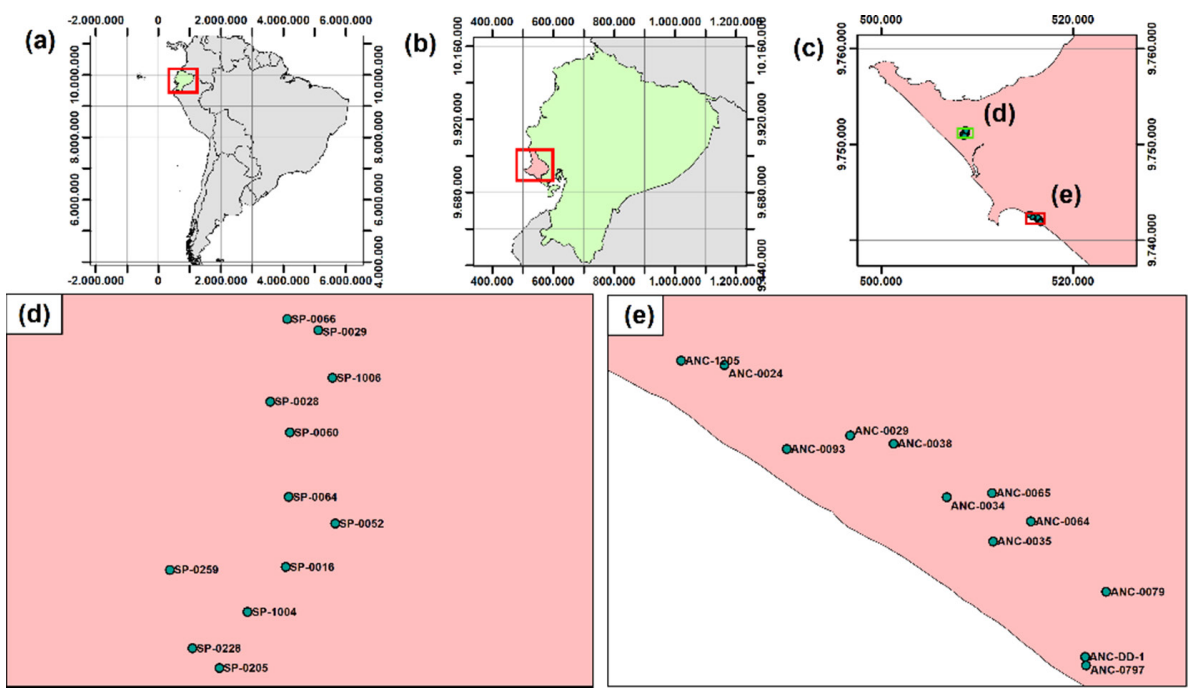

Figure 1: (a) The geographical location of Ecuador; (b) location of the Santa Elena province; (c) selected oil wells in Santa Elena Point; (d) the oil well detail of the urban zone studied (Santa Paula); and (e) the oil well detail of the rural zone studied (Ancón). 
production that depends on water supply, such as livestock and agriculture [33]. However, there are other economic activities such as geotourism (beaches, trails, museums) [34], mining, oil extraction and, in some cases, industrial fishing [35], [36]. Oil wells are close to urban and rural populations, where terrestrial and marine geoenvironmental diversity coexists.

\section{METHODOLOGY}

This research was developed in three phases as shown in Fig. 2: (i) well's inventory and definition of the study area; (ii) definition and characterisation of the polluting factors generated by oil wells to the geoenvironment in operational and non-operational processes, material conditions and state of the infrastructure; (iii) geoenvironmental impact analysis generated from a cause-effect matrix and assessment of the methods and results found from the focus group technique.

\subsection{Well's inventory and definition of the study area}

This phase was approached based on the collection of information from several projects linked (e.g. [37-39]). Tables were drawn up, including location, accessibility, operational

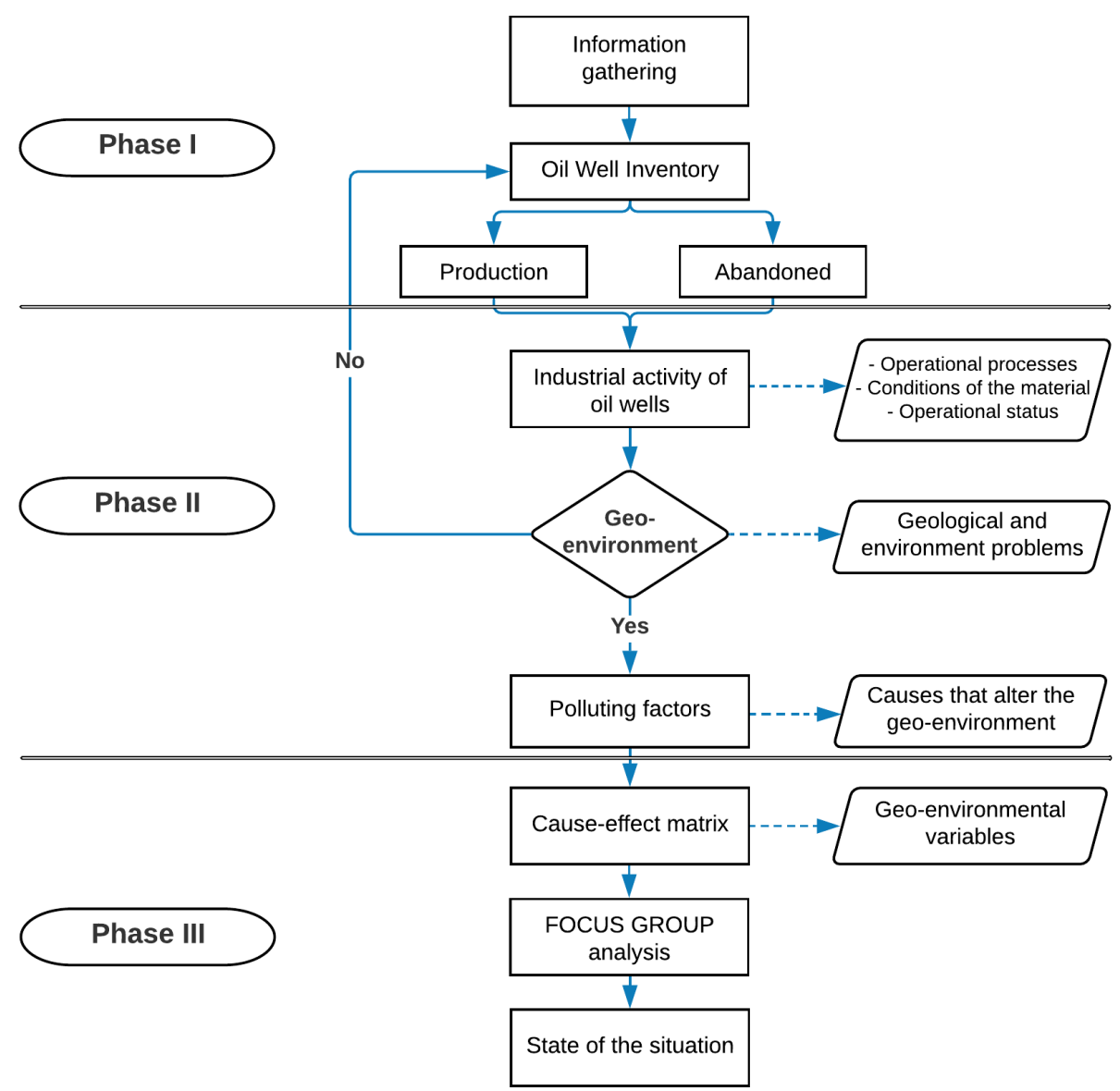

Figure 2: Methodological scheme of the study. 
status and type of pumping. With the information collected, two pilot zones of 24 wells were defined to assess urban and rural zones (Fig. 1c-e).

\subsection{Polluting factors generated by oil wells}

The polluting factors considered in this study were anthropogenic activities that affect or alter the geoenvironmental setting. Factors include current or future risks, which may be caused by wells in production and abandonment states: natural gas release (NGR), state of infrastructure (SS) (mechanical), maintenance processes (MPs) (preventive and corrective), oil fluid (OF) (with rainwater), risk of overflow (RO) (caused by cliff erosion) and lack of signage (LS) (wells with logistical risks). The study generates an analysis of the geoenvironmental components and risks of inhabitants being affected by oil activities. In addition, it presents an assessment of the presence or absence of geoenvironmental components, risks to nearby inhabitants and problems (current and future) for each of the wells studied.

\subsection{Cause and effect matrix, and focus group technique analysis}

This phase applied a cause-effect matrix, a tool that helps identify the environmental impact through a qualitative assessment [40-41]. The tool appears mainly in studies related to environmental impact assessment and analysis. This matrix has a double-entry table indicating environmental factors and impact variables [42]. In this study, the polluting factors replaced the environmental variables to adjust to the problem of oil wells. It is essential to indicate that the impact variables are designed according to the consequences caused by the oil activity to geoenvironmental resources. The variables are character (positive and negative), persistence (temporary and permanent), duration (short and long term), factor (reversible and irreversible) and geoenvironmental (recoverable and non-recoverable).

The evaluation through the focus group technique allows an analysis whereby the opinion of researchers related to the study area is shared, providing a scientific content of qualitative and quantitative context for the social and academic community [43]. In general, this analysis values the interaction of participants, presenting tactics or strategies to solve problems and transform realities [44].

\section{RESULTS}

\subsection{Well's inventory and description}

Table 1 shows the description of the 24 representative wells of the selected pilot zone (urban and rural). The 12 wells in the urban zone, located in Santa Paula, present geoenvironmental contamination and risks to nearby inhabitants. On the other hand, the rural zone, represented by another 12 wells, is located on the Ancón-Anconcito cliff, composed mainly of clay and sand of high porosity. Its structure maintains a constant erosion caused by winds and ocean currents, which causes the risk of overflowing in some wells. Subsequently, it becomes a polluting factor for the geoenvironmental life and rural population of that area. The compilation considers production-abandonment status, coordinates and pumping type.

4.2 Analysis of the polluting factors caused by the selected wells

Table 2 presents the description and analysis of the geoenvironmental problems caused by the 24 selected wells. Considering the urban zone, $50 \%$ of wells present a NGR, another $50 \%$ 
Table 1. Oil wells located in urban and rural pilot zones.

\begin{tabular}{|c|c|c|c|c|c|}
\hline \multirow[b]{2}{*}{ Zone } & \multirow[b]{2}{*}{ No. of well } & \multirow[b]{2}{*}{ Status } & \multicolumn{2}{|c|}{ Coordinates } & \multirow{2}{*}{$\begin{array}{l}\text { Pump- } \\
\text { ing type }\end{array}$} \\
\hline & & & South & West & \\
\hline \multirow{10}{*}{ 完 } & SP-0016 & Production & $2^{\circ} 15^{\prime} 10.0 ” \mathrm{~S}$ & $80^{\circ} 55^{\prime} 16.2^{\prime \prime} \mathrm{W}$ & MP \\
\hline & SP-0028 & Abandoned & $2^{\circ} 14^{\prime} 58.2^{\prime \prime} \mathrm{S}$ & $80^{\circ} 55^{\prime} 17.3 ” \mathrm{~W}$ & - \\
\hline & SP-0029 & Production & $2^{\circ} 14^{\prime} 53.1 " \mathrm{~S}$ & $80^{\circ} 55^{\prime} 13.9^{\prime \prime} \mathrm{W}$ & MP \\
\hline & SP-0052 & Production & $2^{\circ} 15^{\prime} 06.9^{\prime \prime} \mathrm{S}$ & $80^{\circ} 55^{\prime} 12.7^{\prime \prime} \mathrm{W}$ & MP \\
\hline & SP-0060 & Abandoned & $2^{\circ} 15^{\prime} 00.4^{\prime \prime} \mathrm{S}$ & $80^{\circ} 55^{\prime} 15.9^{\prime \prime} \mathrm{W}$ & - \\
\hline & SP-0064 & Production & $2^{\circ} 15^{\prime} 05.0 " \mathrm{~S}$ & $80^{\circ} 55^{\prime} 16.0^{\prime \prime} \mathrm{W}$ & MP \\
\hline & SP-0066 & Abandoned & $2^{\circ} 14 ' 52.3 " \mathrm{~S}$ & $80^{\circ} 55^{\prime} 16.1$ 'W & - \\
\hline & SP-0205 & Production & $2^{\circ} 15^{\prime} 17.2 ” S$ & $80^{\circ} 55^{\prime} 20.9^{\prime \prime} \mathrm{W}$ & LT \\
\hline & SP-0228 & Production & $2^{\circ} 15^{\prime} 15.8 ” S$ & $80^{\circ} 55^{\prime} 22.8^{\prime \prime} \mathrm{W}$ & MP \\
\hline & SP-0259 & Production & $2^{\circ} 15^{\prime} 10.2^{\prime \prime S}$ & $80^{\circ} 55^{\prime} 24.4^{\prime \prime} \mathrm{W}$ & MP \\
\hline \multirow{14}{*}{ בี } & SP-1004 & Production & $2^{\circ} 15^{\prime} 13.2^{\prime \prime} \mathrm{S}$ & $80^{\circ} 55^{\prime} 18.9^{\prime \prime} \mathrm{W}$ & MP \\
\hline & SP-1006 & Production & $2^{\circ} 14^{\prime} 56.5 ” \mathrm{~S}$ & $80^{\circ} 55^{\prime} 12.9^{\prime \prime} \mathrm{W}$ & LT \\
\hline & ANC-0024 & Production & $2^{\circ} 19^{\prime} 41.5 ” \mathrm{~S}$ & $80^{\circ} 51^{\prime} 35.6 ” \mathrm{~W}$ & MP \\
\hline & ANC-0029 & Abandoned & $2^{\circ} 19^{\prime} 48.2^{\prime \prime} \mathrm{S}$ & $80^{\circ} 51^{\prime} 23.7^{\prime \prime} \mathrm{W}$ & - \\
\hline & ANC-0034 & Abandoned & $2^{\circ} 19^{\prime} 54.1 " \mathrm{~S}$ & $80^{\circ} 51^{\prime} 14.6 " \mathrm{~W}$ & - \\
\hline & ANC-0035 & Production & $2^{\circ} 19^{\prime} 58.3 ” S$ & $80^{\circ} 51^{\prime} 10.2^{\prime \prime} \mathrm{W}$ & LT \\
\hline & ANC-0038 & Abandoned & $2^{\circ} 19^{\prime} 49.0 " \mathrm{~S}$ & $80^{\circ} 51^{\prime} 19.6$ "W & - \\
\hline & ANC-0064 & Production & $2^{\circ} 19^{\prime} 56.4^{\prime \prime} \mathrm{S}$ & $80^{\circ} 51^{\prime} 06.6^{\prime \prime} \mathrm{W}$ & SW \\
\hline & ANC-0065 & Production & $2^{\circ} 19^{\prime} 53.7^{\prime \prime S}$ & $80^{\circ} 51^{\prime} 10.3^{\prime \prime} \mathrm{W}$ & SW \\
\hline & ANC-0079 & Production & $2^{\circ} 20^{\prime} 03.1 ” S$ & $80^{\circ} 50^{\prime} 59.5^{\prime \prime} \mathrm{W}$ & LT \\
\hline & ANC-0093 & Production & $2^{\circ} 19^{\prime} 49.5 ” \mathrm{~S}$ & $80^{\circ} 51^{\prime} 29.7^{\prime \prime} \mathrm{W}$ & MP \\
\hline & ANC-0797 & Production & $2^{\circ} 20 ' 10.1 " \mathrm{~S}$ & $80^{\circ} 51^{\prime} 01.4^{\prime \prime} \mathrm{W}$ & SW \\
\hline & ANC-1205 & Production & $2^{\circ} 19^{\prime} 41.1$ 'S & $80^{\circ} 51^{\prime} 39.7^{\prime \prime} \mathrm{W}$ & MP \\
\hline & ANC-DD-1 & Production & $2^{\circ} 20$ '09.3"S & $80^{\circ} 51^{\prime} 01.5 ” \mathrm{~W}$ & SW \\
\hline
\end{tabular}

MP, Mechanical Pumping; LT, Local Tool; SW, Swab.

have a lack of signage (LS), $46 \%$ have a poor state of infrastructure (SS), and $58 \%$ have oil flow (OF) on the surface. On the other hand, the rural zone presents a similar picture, where $50 \%$ of wells have NGR and poor state of infrastructure (SS). Forty-seven percent of wells show a lack of signalling (LS) and oil flow (OF) at the surface, and only $8 \%$ show risks in maintenance processes (MPs). In addition, there are $25 \%$ of wells in the Ancon Cliff at risk of overflowing (RO). 
Table 2. General description and contaminating factors of selected wells.

No. of well Description

Polluting

factors

The well maintains a productive activity, which causes a partial

SP-0016 release of natural gas and a rusty valve infrastructure. The lack of signage is essential, as there is a vegetated and inhabited

NGR, SS, zone 40-60 m away

SP-0028 The well is currently inactive, as it has no productive activity. However, vegetation covers part of its wellhead. It presents a partial release of natural gas that negatively affects the geoenvironmental setting

SP-0029 Around the well, there is a vegetation zone and a constant

OF, LS presence of settlers. The polluting factors are the presence of hydrocarbons with rainwater and the lack of signposting

SP-0052 The well is located $15 \mathrm{~m}$ from vegetation zones, home to reptiles, land birds and insects. It presents contaminating factors like the presence of hydrocarbons on the soil's surface and the constant release of natural gas

SP-0060 The well is in a state of abandonment, located in a vegetation zone. Some animals and plants surround the oil well. The partial release of natural gas alters the geoenvironmental

SP-0064 A vegetative environment surrounds the well with partial alterations caused by the presence of hydrocarbons and rusted

NGR

LS infrastructure. There is a vehicular presence within $25 \mathrm{~m}$ of the well, making it essential to signage

SP-0066 The well is in a state of abandonment, located $17 \mathrm{~m}$ from a vegetation zone and $40 \mathrm{~m}$ from populated zones. The polluting factors are corrosive infrastructure and lack of signage

SP-0205 The well maintains a petroleum production that generates a release of natural gas. It is $7 \mathrm{~m}$ from a vegetation zone and 5 $\mathrm{m}$ from the urban population. Animals like reptiles, birds and domestic animals coexist in the area

SP-0228 The well is close to vegetation and inhabited houses. It has contaminating factors like the high presence of hydrocarbon with rainwater, corrosion in the infrastructure and partial release of natural gas

SP-0259 The well maintains petroleum production with 'Mechanical Pumping' (MP). There is a sea inlet $20 \mathrm{~m}$ to the west of the well and houses $30 \mathrm{~m}$ to the east of the well, and a natural hydrocarbon outcrop $20 \mathrm{~m}$ (north of the well)

SS, LS

SS, OF

SS, OF,

LS

NGR, LS

NGR, SS, OF

(Continued) 
Table 2. Cont.

\begin{tabular}{|c|c|c|}
\hline No. of well & Description & $\begin{array}{l}\text { Polluting } \\
\text { factors }\end{array}$ \\
\hline SP-1004 & $\begin{array}{l}\text { Petroleum production is by 'Mechanical Pumping' (MP). It is } \\
10 \mathrm{~m} \text { from vegetation and } 30 \mathrm{~m} \text { from the population. There are } \\
\text { polluting factors like the presence of hydrocarbons with rainwa- } \\
\text { ter and lack of signage }\end{array}$ & OF, LS \\
\hline SP-1006 & $\begin{array}{l}\text { The well has type pumping 'Local Tool' (LT). It is } 35 \mathrm{~m} \text { from } \\
\text { a vegetation zone and } 14 \mathrm{~m} \text { from a populated zone. There are } \\
\text { contaminating factors like the presence of hydrocarbon and } \\
\text { partial release of natural gas }\end{array}$ & $\mathrm{OF}$ \\
\hline ANC-0024 & $\begin{array}{l}\text { There is petroleum production by 'Mechanical Pumping' (MP). } \\
\text { It is } 30 \mathrm{~m} \text { from a populated area. There are contaminating fac- } \\
\text { tors like hydrocarbons in sandy-clay soil and infrastructure in a } \\
\text { corrosive state. }\end{array}$ & $\mathrm{SS}, \mathrm{OF}$ \\
\hline ANC-0029 & $\begin{array}{l}\text { The well is abandoned, with a production of natural gas distrib- } \\
\text { uted through an external pipeline system. It is in a rural zone, } \\
\text { which means a high risk for the inhabitants }\end{array}$ & MPs \\
\hline ANC-0034 & $\begin{array}{l}\text { Although there is no petroleum production in the well, there } \\
\text { are polluting factors like the release of natural gas and a lack of } \\
\text { signage. These factors have an impact on the geoenvironmental } \\
\text { contamination of the vegetation zone }\end{array}$ & NGR, LS \\
\hline ANC-0035 & $\begin{array}{l}\text { The well has type pumping LT. The location of the well shows a } \\
\text { vegetated environment at } 10 \mathrm{~m} \text { and inhabited houses at } 35 \mathrm{~m} \text {. Con- } \\
\text { taminating factors were the presence of hydrocarbon and NGR }\end{array}$ & NGR, OF \\
\hline ANC-0038 & $\begin{array}{l}\text { The well has no petroleum production; its location is } 12 \mathrm{~m} \text { from } \\
\text { a populated area and } 20 \mathrm{~m} \text { from a vegetated area. Contaminat- } \\
\text { ing factors are NGR and infrastructure corrosion }\end{array}$ & NGR, SS \\
\hline ANC-0064 & $\begin{array}{l}\text { The well is located } 5 \mathrm{~m} \text { from a vegetation zone, where reptile } \\
\text { and insect species live. It presents contaminating factors such } \\
\text { as hydrocarbon fluid with rainwater, constant release of natural } \\
\text { gas and lack of signage }\end{array}$ & $\begin{array}{l}\text { NGR, } \\
\text { OF, LS }\end{array}$ \\
\hline ANC-0065 & $\begin{array}{l}\text { The well has petroleum production 'Swab' (SW) pumping. It is } \\
3 \mathrm{~m} \text { from a vegetation zone and } 20 \mathrm{~m} \text { from a rural population. } \\
\text { The polluting factors are the presence of hydrocarbon, NGR } \\
\text { and lack of signage }\end{array}$ & $\begin{array}{l}\text { NGR, } \\
\text { OF, LS }\end{array}$ \\
\hline ANC-0079 & $\begin{array}{l}\text { The well is producing LT. It is } 3 \mathrm{~m} \text { from a vegetative zone with } \\
\text { reptile species and land and sea birds. The presence of hydro- } \\
\text { carbon in the clay soil alters the geoenvironmental }\end{array}$ & OF \\
\hline ANC-0093 & $\begin{array}{l}\text { The well is in a rural environment at } 47 \mathrm{~m} \text {. Species of land birds, } \\
\text { reptiles and insects were observed. This well has contaminating } \\
\text { factors like the RO, valves and pipes with corrosion }\end{array}$ & SS, RO \\
\hline
\end{tabular}


Table 2. Cont.

\begin{tabular}{lll}
\hline No. of well & Description & \multicolumn{1}{c}{$\begin{array}{l}\text { Polluting } \\
\text { factors }\end{array}$} \\
\hline ANC-0797 & $\begin{array}{l}\text { The well is in an isolated environment, on the edge of the cliff. } \\
\text { Production carried out using the Swab method. It presents pol- } \\
\text { luting factors like the risk of overflowing due to cliff erosion, } \\
\text { worn metal profile and lack of signposting }\end{array}$ & LS \\
ANC-1205 & $\begin{array}{l}\text { This well produces oil using the 'Mechanical Pumping' (MP) } \\
\text { method. Although there is a low index of animal species, the } \\
\text { corrosive infrastructure harms the geoenvironmental setting }\end{array}$ & SS \\
ANC-DD-1 & $\begin{array}{l}\text { Its location is not related to marine or terrestrial fauna. How- } \\
\text { ever, it has contaminating factors like the release of natural gas, } \\
\text { oil flow, probability of overflow, state of the metal contour and } \\
\text { lack of signage }\end{array}$ & NGR, SS, \\
\hline
\end{tabular}

NGR, natural gas release; SS, structure state; MP, maintenance process; OF, oil flow; RO, risk of overflow; LS, lack of signage.

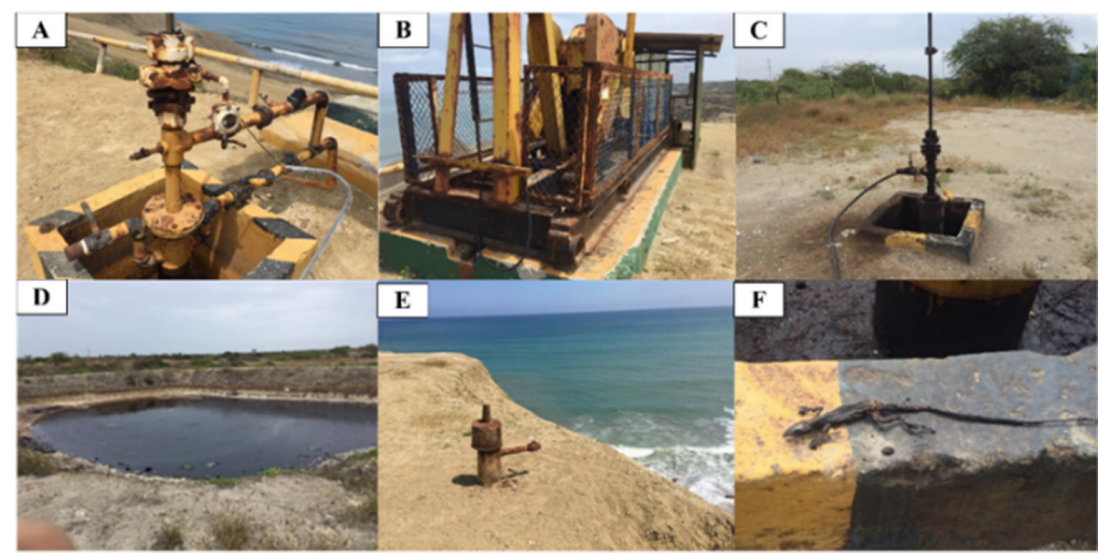

Figure 3. Polluting factors of selected wells: (a) SP-259; (b) SP-0052; (c) and (d) ANC-1205; (e) ANC-0029; (f) ANC-0797; (g) ANC-0064.

Figure 3 shows the images of the factors with the highest risk of geoenvironmental contamination. More specifically, Fig. 3a and b shows the deterioration of the metal structure of the ANC-1205 shaft at the head, rods and rocker arm profile. Figure 3d shows a natural outcrop $20 \mathrm{~m}$ north of well SP-0259. There are seabird and land bird species at this site and a seawater inlet $20 \mathrm{~m}$ to the west of the well. In Fig. 3c, there is oil flow and residue in well SP-0052, with a natural gas emission releasing hydrocarbon particle to the ground. Figure 3e shows that there is a RO from well ANC-0797. Figure $3 \mathrm{f}$ shows geobiological alteration by contaminating factors in borehole ANC-0064. 
Table 3 shows the geoenvironmental components, risks to nearby inhabitants and, in addition, the current and future problems of contamination by oil wells. Ninety-five percent of the wells emit contamination to clay soils, while $17 \%$ to sandy soils. $16.7 \%$ of the wells are related to the marine environment (saltwater) and $12.5 \%$ to freshwater, while $15 \%$ of the wells pollute the air by NGR. Subsequently, the wells could generate a risk to the nearby inhabitants, such as the olfactory sensation of gas (OSG), the petroleum residue (PR) and the accident risk (AR).

Table 3: Geoenvironment, population and problems related to selected wells.

\begin{tabular}{|c|c|c|c|c|c|c|c|c|}
\hline \multirow[b]{2}{*}{ No. of well } & \multicolumn{3}{|c|}{$\begin{array}{l}\text { Contaminated } \\
\text { geoenvironmental }\end{array}$} & \multicolumn{3}{|c|}{$\begin{array}{c}\text { Risks to } \\
\text { inhabitants }\end{array}$} & \multicolumn{2}{|c|}{ Problems } \\
\hline & Soil & Water & Air & OSG & PR & $\mathbf{A R}$ & Current & Future \\
\hline SP-0016 & $\mathrm{X}$ & & & & & $\mathrm{X}$ & $\mathrm{X}$ & \\
\hline SP-0028 & $\mathrm{X}$ & & & $\mathrm{X}$ & & & $\mathrm{X}$ & \\
\hline SP-0029 & & & & & $X$ & $\mathrm{X}$ & $X$ & $X$ \\
\hline SP-0052 & $\mathrm{X}$ & $X$ & $\mathrm{X}$ & $\mathrm{X}$ & $X$ & $\mathrm{X}$ & $\mathrm{X}$ & $\mathrm{X}$ \\
\hline SP-0060 & $\mathrm{X}$ & & & & $X$ & & $\mathrm{X}$ & \\
\hline SP-0064 & $\mathrm{X}$ & & & & $\mathrm{X}$ & & $\mathrm{X}$ & \\
\hline SP-0066 & $\mathrm{X}$ & & & & & $X$ & & $\mathrm{X}$ \\
\hline SP-0205 & $\mathrm{X}$ & & & $X$ & & $\mathrm{X}$ & & $\mathrm{X}$ \\
\hline SP-0228 & $X$ & & & & $\mathrm{X}$ & $\mathrm{X}$ & $\mathrm{X}$ & $\mathrm{X}$ \\
\hline SP-0259 & $X$ & $X$ & & & $X$ & $\mathrm{X}$ & $X$ & $\mathrm{X}$ \\
\hline SP-1004 & $\mathrm{X}$ & & & & $\mathrm{X}$ & $\mathrm{X}$ & $\mathrm{X}$ & \\
\hline SP-1006 & $\mathrm{X}$ & $X$ & & $\mathrm{X}$ & & & & $\mathrm{X}$ \\
\hline ANC-0024 & $\mathrm{X}$ & & & & & $\mathrm{X}$ & & $\mathrm{X}$ \\
\hline ANC-0029 & $\mathrm{X}$ & & & & & $\mathrm{X}$ & & $\mathrm{X}$ \\
\hline ANC-0034 & $\mathrm{X}$ & & & $X$ & & & $\mathrm{X}$ & \\
\hline ANC-0035 & $\mathrm{X}$ & & $\mathrm{X}$ & & $\mathrm{X}$ & & $\mathrm{X}$ & \\
\hline ANC-0038 & $\mathrm{X}$ & & & & $\mathrm{X}$ & & $\mathrm{X}$ & \\
\hline ANC-0064 & $\mathrm{X}$ & & $\mathrm{X}$ & & $\mathrm{X}$ & & $\mathrm{X}$ & \\
\hline ANC-0065 & $\mathrm{X}$ & & & $\mathrm{X}$ & & & $\mathrm{X}$ & $\mathrm{X}$ \\
\hline ANC-0079 & $X$ & & & & $\mathrm{X}$ & & $X$ & \\
\hline ANC-0093 & $X$ & $X$ & & & & $X$ & & $\mathrm{X}$ \\
\hline ANC-0797 & & $X$ & & & & $X$ & & $X$ \\
\hline ANC-1205 & $\mathrm{X}$ & & & & & $\mathrm{X}$ & $\mathrm{X}$ & $\mathrm{X}$ \\
\hline ANC-DD-1 & $\mathrm{X}$ & $\mathrm{X}$ & $\mathrm{X}$ & $X$ & $X$ & $X$ & $X$ & $X$ \\
\hline
\end{tabular}

OSG, olfactory sensation of gas; PR, petroleum residue; AR, accident risk. 
The geoenvironment in the urban zone is affected by $58 \%$ of wells causing oil residues and sometimes an olfactory sensation of natural gas, and $67 \%$ maintain a risk of flammable accidents. On the other hand, the rural zone shows a less polluted environment, as $50 \%$ of the wells present severe contamination risks towards the populated section. However, $25 \%$ of the wells have an OSG, and more than $40 \%$ have oil residues and cliff overflow risks. Finally, there are current and future problems caused by oil wells in the pilot zones. This information indicates the persistence of current problems, generally caused by severe NGR, which influences minor geoenvironmental degradation. However, 58\% of the wells will cause future geoenvironmental problems, mainly by those wells with the significant NGR, RO and oil flow $(\mathrm{OF})$.

\subsection{Cause-effect matrix}

The analysis of the cause-effect matrix provided qualitative information on geoenvironmental impacts. The results obtained are presented in Table 4 as follows: (i) Character: factor analysis indicates that any action caused by oil wells has a negative impact $(\mathrm{N})$ on the geoenvironmental setting; (ii) Persistence: commonly encountered factors such as NGR, SS, MPs and LS have temporary effects (Tm). On the other hand, the presence of oil and overflows are permanent risks $(\mathrm{Pm})$. Accidents caused by $\mathrm{OF}$ and RO cause volumes of toxic components, negatively altering the geoenvironment; (iii) Duration: half of the polluting factors cause short-term (ST) geoenvironmental damage, signifying the same amount in the long term (LT); (iv) Factor: most of the factors are irreversible like natural gas, oil flow and overflows, which release hydrocarbons into the geoenvironment; (v) Geoenvironment: the analysis indicates that the geoenvironmental may be recoverable $(\mathrm{Rc})$ when factors severely impact on NGR, SS and MPs actions. On the other hand, contamination from $\mathrm{OF}$ and $\mathrm{RO}$ accidents are not $100 \%$ recovered, as the oil remains in the porous medium of the soil (oil residue).

Table 4: Cause-effect matrix of polluting factors.

\begin{tabular}{|c|c|c|c|c|c|c|c|c|c|c|}
\hline \multirow[b]{2}{*}{ Polluting factors } & \multicolumn{2}{|c|}{ Character } & \multicolumn{2}{|c|}{ Persistence } & \multicolumn{2}{|c|}{ Duration } & \multicolumn{2}{|c|}{ Factor } & \multicolumn{2}{|c|}{$\begin{array}{l}\text { Geoenvi- } \\
\text { ronment }\end{array}$} \\
\hline & $\mathbf{P}$ & $\mathbf{N}$ & $\mathbf{T m}$ & Pm & ST & LT & $\mathbf{R v}$ & Iv & $\mathbf{R c}$ & NRc \\
\hline Natural gas release & & & & & & & & & & \\
\hline Infrastructure status & & & & & & & & & & \\
\hline Maintenance processes & & & & & & & & & & \\
\hline Presence of petroleum & & & & & & & & & & \\
\hline Wells at risk of overflow & & & & & & & & & & \\
\hline $\begin{array}{l}\text { Consequences by lack of } \\
\text { signage }\end{array}$ & & & & & & & & & & \\
\hline
\end{tabular}

P, positive; N, negative; Tm, temporary; Pm, permanent; ST, short term; LT, long term; Rv, reversible; Iv, irreversible; Rc, recoverable; NRc, non-recoverable. 


\subsection{Focus group technique analysis}

This analysis ratifies geoenvironmental problems, mainly caused by corrosion in the metallic material of the well and lack of geoenvironmental control in the operation processes. The type of environment affects the composition of the material (existence of corrosive components) and the instability of the wells. Contaminating factors have a high risk of existence in the area due to the situation of the wells and the lack of industrial control. The analysis recommends developing a strategic plan by the entities in charge to avoid geoenvironmental damage to marine and terrestrial ecosystems. Sustainable strategies like the Peninsula Santa Elena Geopark project, which has an inventory of geosites, are currently being implemented. The geopark includes urban and rural zones, where certain geosites have oil activity and natural hydrocarbon outcrops (bituminous oozes) [45]. Geosites help protecting the geoenvironment from anthropogenic actions, strengthening the geo-conservation of heritage sites (rural zone, Ancón) [46-47] and encouraging geotourism [48-49].

\section{DISCUSSION}

The analysis developed shows the polluting factors by oil wells in the pilot zones (Fig. 1). Selected wells cause geoenvironmental disturbances from the release of natural gas, deteriorating infrastructure and oil flow in the surrounding zones. Also, there is an evident lack of maintenance and preventive signposting of the wells' situation (Table 2). Frequent polluting factors were the partial and constant release of natural gas, oil in the soil and corrosion of infrastructure. Since the beginning of oil exploitation (100 years ago), there have been contamination levels towards the geoenvironment in the south of the province [23]. According to Tomalá et al. [50], there is a need to improve petroleum hydrocarbon remediation methods to reduce geoenvironmental degradation problems in the province. In addition, Herrera et al. [23] carried out a study of the environmental impact of anthropogenic activities, indicating that there is a 'medium level' of contamination by industrial activities on the geological and biological environment. On the other hand, studies carried out by Botero et al. [51] show that there is no oil pollution in coastal geo-environmental zones. However, Rodríguez Martínez et al. [52] demonstrated more specific data, finding oil in environmental zones. Although there is pollution, oil wells do not demonstrate significant environmental disturbance as caused mainly by nearby refineries. This criterion is reflected in the data found in this study, where approximately $90 \%$ of the oil wells cause intermediate and low damage, as the geo-environmental alterations would be caused by secondary systems such as geological activity and population expansion in the area.

The characterised wells show contamination in different geoenvironment, mainly in clay soils, seawater and air environment. Wells SP-0228, ANC-0064, ANC-0065 and ANC-DD-1 cause a further geoenvironmental disturbance. These wells emit a greater flow of natural gas to the surface. The relationship between contaminating factors and natural activity in the environment determines the likelihood of contamination risk (importance of oil well location): (i) accidents inside well: the layers may exert collateral pressure on the casing, causing subsoil contamination and soil coverage; (ii) corrosion wear in pipelines: the coastal environment exerts components that cause wear in the pipe profile, releasing fluids that reach the surface through the highly porous subsoil layers. In some cases, there is a possibility of overflow due to cliff erosion.

The cause-effect matrix presents the risk of contamination of the factors based on a geoenvironmental consequence perspective (Table 4). Polluting factors have consequences to the 
geoenvironment, with possible solutions or permanent damage. Concerning permanent factors, these lead to geoenvironmental degradation consequences, affecting the environment over a prolonged period, like oil flow and well overflow accidents. Partial factors have temporary consequences that may be recoverable from geoenvironmental ecosystems, such as natural gas emissions, corrosive infrastructure and maintenance processes. The study by Chipe and Panchana [25] indicates the impact of oil wells in the south of the province, where oil flow has a high pollution rate $(47.6 \%)$. On the other hand, natural gas emissions have a low environmental impact (36.6\%) but contribute to climate change through greenhouse gas emissions. Our study finds that an average of $50 \%$ of wells generates natural gas emissions and oil flow, impacting geoenvironmental components and the human population.

\section{CONCLUSIONS}

The paper has typified the geoenvironmental problems caused by the 24 selected oil wells (12 in urban and 12 in rural zones). The wells show different polluting factors that alter the geoenvironment of marine, terrestrial and aerial ecosystems. The geoenvironmental impact is mainly due to NGR (partial and constant), presence of oil flow (fluid and residue) and well structure conditions (corrosion-wear). Other factors are the risks of overflows, maintenance processes and lack of signage. The results allow proposing some prevention, control and correction measures to ensure better conditions for the geoenvironment.

The variety of polluting factors can cause temporary or permanent, short- or long-term effects. There are also reversible and irreversible pollution factors, with recoverable and non-recoverable environmental solutions. The wells studied have been classified according to these factors, which impact the geoenvironmental setting and population occupation of urban and rural zones, with oil residues on the ground and the OSG. Finally, the analysis presents the brevity of the geoenvironmental consequences and the likelihood of future industrial accidents. Regarding current problems, $50 \%$ of the wells have partial NGR, $46 \%$ have SS and LS, and $50 \%$ have OF at the surface. In addition, between $4 \%$ and $12 \%$ of the wells show RO and MPs contamination. Moreover, future problems show that $58 \%$ of the wells have a higher incidence of steady NGR, OF and RO.

The existing problems (geoenvironmental pollution, OSG, PR and AR) lead to a series of environmental strategies: (i) using the natural gas released through an internal pipeline system to supply the nearby population; (ii) generate preventive maintenance on the metal structure of abandoned and producing wellheads; (iii) controlling the flow of oil in extraction processes and remediating contaminated soil in the surroundings; (iv) implementing logistical strategies in wells at risk of overflowing through links between private enterprise and government agencies; (v) implement signage in wells with risks of accidents and geoenvironmental contamination. In general, knowledge of geoenvironmental problems and shared strategies will help to encourage geoenvironmental projects and engineering for land-use planning. In addition, the methodology presented is simple to apply and can be expanded to the whole zone and will share guidelines for land-use planning, as to generate a logistical inventory of the 2,900 wells located in the field and, subsequently, a study of sustainable strategies through geo-environmental analysis (in a general and specific context) of the wells.

\section{ACKNOWLEDGEMENTS}

This work was carried out in collaboration with the 'Peninsula Santa Elena Geopark Project' with code no. 91870000.0000 .381017 , and 'Factores Geoambientales de los pozos petroleros y su incidencia en el desarrollo territorial en los cantones Salinas y La Libertad de la 
provincia de Santa Elena', with code no: 91870000.0000 .385428 , by UPSE University. Support for the project was also provided by the 'Registry of geological and mining heritage and its impact on the defence and preservation of geodiversity in Ecuador', academic research project by ESPOL University, CIPAT-01-2018.

\section{REFERENCES}

[1] Valdivia, G., Governing relations between people and things: Citizenship, territory, and the political economy of petroleum in Ecuador. Political Geography, 27(4), pp. 456-477, May 2008. https://doi.org/10.1016/j.polgeo.2008.03.007

[2] Cepeda Chacaguasay, P., Los ingresos petroleros y el crecimiento económico en Ecuador (2000-2015) (The oil revenues and economic growth in Ecuador (2000-2015)). Rev. Investig. Altoandinas - Journal of High Andean Research, 18(4), pp. 459-466, 2016. https://doi.org/10.18271/ria.2016.238

[3] Villafuerte, J. \& Intriago, E., Productive matrix change in Ecuador and the petroleum crisis. Case study: Entrepreneurs and productive associations. Journal of Business, 1(2), pp. 1-11, 2016. https://doi.org/10.18533/job.v1i2.18

[4] Verma, C., Alrefaee, S.H., Quraishi, M.A., Ebenso, E.E. \& Hussain, C.M., Environmental, safety and economic risks of Covid-19 pandemic in petroleum industries: A prospective. Journal of Petroleum Science \& Engineering, 198, p. 108161, 2021. https://doi.org/10.1016/j.petrol.2020.108161

[5] Pablo Mateo, J. \& García, S., El sector petrolero en Ecuador. 2000-2010 (The oil sector in Ecuador. 2000-2010). Problemas del Desarrollo, 45(177), pp. 113-139, 2014. https://doi.org/10.1016/S0301-7036(14)70865-X

[6] Beittel, J.S., Ecuador: Political and Economic Conditions and U. S. Relations, R43135, Congressional Research Service, USA, 2013.

[7] Suslick, S.B. \& Schiozer, D.J., Risk analysis applied to petroleum exploration and production: An overview. Journal of Petroleum Science \& Engineering, 44(1-2), pp. 1-9, 2004. https://doi.org/10.1016/j.petrol.2004.02.001

[8] Baynard, C.W., Ellis, J.M. \& Davis, H., Roads, petroleum and accessibility: The case of eastern Ecuador. GeoJournal, 78(4), pp. 675-695, 2013, https://doi.org/10.1007/ s10708-012-9459-5

[9] Bass, M.S., et al., Global conservation significance of Ecuador's Yasuní National Park. PLOS One, 5(1), e8767, 2010. https://doi.org/10.1371/journal.pone.0008767

[10] López Acevedo, V., Espíndola, F., Calles, J. \& Ulloa, J., Amazonía Ecuatoriana Bajo Presión (Ecuadorian Amazon Under Pressure). Quito-Ecuador: EcoCiencia, 2013.

[11] Lessmann, J., Fajardo, J., Muñoz, J. \& Bonaccorso, E., Large expansion of oil industry in the Ecuadorian Amazon: biodiversity vulnerability and conservation alternatives. Ecology \& Evolution, 6(14), pp. 4997-5012, 2016. https://doi.org/10.1002/ece3.2099

[12] Fontaine, G., Petróleo y desarrollo sostenible en Ecuador: reglas de juego (Oil and sustainable development in Ecuador: rules of the game). FLACSO \& GPA Petroecuador: Quito, 2003.

[13] Ministerio de Ambiente y Agua, Ley de Hidrocarburo, 1978 (Hydrocarbon Law, 1978), Quito, Ecuador, 2967, 2018. https://www.ambiente.gob.ec/wp-content/uploads/downloads/2018/05/Ley-de-Hidrocarburos-1978.pdf

[14] Asamblea Nacional de Ecuador, Proyecto de Ley Orgánica de Ordenamiento Territorial, Uso y Gestión de Suelo (Draft Organic Law on Land Planning, Land Use and Management), 2016. https://www.habitatyvivienda.gob.ec/wp-content/uploads/ 
downloads/2015/11/PROYECTO-DE-LEY-ORGANICA-DE-ORDENAMIENTOTERRITORIAL20-11-2014.pdf

[15] Álvarez Loor, A., Herrera Franco, G. \& Erazo Mora, K., Ancón Santa-Elena: HistoriaPatrimonio-Geoparque (Ancón Santa-Elena: History-Heritage-Geopark), I. Universidad Estatal Península de Santa Elena, 2015.

[16] Pacifpetrol, Pacifpetrol S. A., 2019. https://www.pacifpetrol.com/, accessed April 12, 2021.

[17] Lorenzo, E., Roca-Beltrán, W.A., Martínez, M., Morato, A., Escandón-Panchana, P.C. \& Álvarez-Domínguez, C.P., Correlación geoquímica entre crudos y rocas del sistema petrolero de la península de Santa Elena y el golfo de Guayaquil (Geochemical correlation between crude oils and rocks of the petroleum system of the Santa Elena Peninsula and the Gulf of Guayaquil). Boletín Geol., 40(1), pp. 31-42, 2018, https:// doi.org/10.18273/revbol.v40n1-2018002

[18] Ortiz, V., Plan de mejoras para las operaciones portuarias en el puerto petrolero la Liberta en Santa Elena en el periodo 2015 - 2018 (Improvement plan for port operations in the oil port of La Liberta in Santa Elena in the period 2015-2018), Universidad Tecnológica Empresarial de Guayaquil, 2016.

[19] Ziritt, J.L., El Petróleo en Cifras (Oil in Numbers), Quito, Ecuador, 2012.

[20] Ventura, L., Identificación, evaluación, análisis y prevención de los riegos para mitigar el impacto en la salud de los habitantes de la ciudadela las minas provocadas por la cercanía de los pozos petroleros en el cantón La Libertad (Identification, Evaluation, Analysis and Prevention of Risks to Mitigate the Impact on the Health of the Inhabitants of Ciudadela Las Minas Caused by the Proximity of Oil Wells in the Canton of La Libertad), Universidad Estatal Península de Santa Elena, 2013.

[21] Petroecuador, EP Petroecuador, 2021. https://www.eppetroecuador.ec/, accessed April 13, 2021.

[22] Pacifpetrol, Departamentos (Departments), Pacifpetrol S.A., 2018. https://www.pacifpetrol.com/es/departamentos, accessed April 13, 2021.

[23] Herrera-Franco, G., Mora-Frank, C. \& Rubira, G., Affectations by anthropogenic activities of urban, rural and industrial zone in geosites of the Santa Elena peninsula Geopark Project, Ecuador Gricelda. Proceedings of the 18th LACCEI International MultiConference for Engineering, Education and Technology: Engineering, Integration and Alliances for a Sustainable Development, Hemispheric Cooperation for Competitiveness and Prosperity on a Knowledge-Bas, October, 2020, https://doi.org/10.18687/ LACCEI2020.1.1.200

[24] Barreto, R., Incidencia de la Contaminación por los Desechos de Hidrocarburos de Petróleo en el Ecosistema Marino (Incidence of Pollution by Petroleum Hydrocarbon Wastes in the Marine Ecosystem), Sector Carioca cantón La Libertad, 2014, Universidad Estatal Península de Santa Elena, 2015.

[25] Chipe del Pezo, L. \& Panchana, F., Estudio de los pozos productivos y abandonados como fuente de contaminación de hidrocarburos y su impacto ambiental en el sector de Santa Paula del cantón Salinas (Study of productive and abandoned wells as a source of hydrocarbon contamination and their environmental impact in the Santa Paula sector of the Salinas canton), Universidad Estatal Península de Santa Elena, 2015.

[26] Suárez, J., Identificación y Evaluación de Riesgos en Petroindustrial Refinería La Libertad (Identification and Evaluation of Risks in Petroindustrial Refinery La Libertad), Repositorio Universidad de Guayaquil, 2014. 
[27] Gobierno Autónomo Descentralizado Provincial de Santa Elena, Plan de Desarrollo y Ordenamiento Territorial Provincial 2015-2019 (Provincial Land Use and Development Plan 2015-2019), 2015.

[28] Gobierno Autónomo Descentralizado Municipal del Cantón Salinas, Plan de Desarrollo y Ordenamiento Territorial del Cantón Salinas (Development and Land Use Plan for the Salinas Canton), 2014.

[29] Asamblea Nacional de Ecuador, Ley Orgánica de Ordenamiento Territorial, Uso y Gestión de Suelo (Organic Law on Land Planning, Land Use and Management), Quito, Ecuador, SAN-2016-1196, 2016. https://www.habitatyvivienda.gob.ec/wp-content/ uploads/downloads/2016/08/Ley-Organica-de-Ordenamiento-Territorial-Uso-yGestion-de-Suelo1.pdf

[30] Herrera, G., Álvarez, A. \& Alvarado, N., Geoparque Ancón-Santa Elena: Una Vía para el Desarrollo Local (Ancón-Santa Elena Geopark: A Way to Local Development). La Minería y la Geol. Ambient. herramientas para el Desarro. sostenible, para el Present. Futur. Guadalajara Soc. Española para la Def. del Patrim. Geológico y Min., 1(1), pp. 355-369, 2016.

[31] Herrera-Franco, G., Carrión-Mero, P., Mora-Frank, C. \& Caicedo-Potosí, J., Comparative analysis of methodologies for the evaluation of geosites in the context of the Santa Elena-Ancón Geopark Project. International Journal of Design and Nature \& Ecodynamics, 15(2), pp. 183-188, 2020. https://doi.org/10.18280/ijdne.150207

[32] El clima promedio en Santa Elena (The average climate in Santa Elena). Weather Spark. https://es.weatherspark.com/y/18289/Clima-promedio-en-Santa-Elena-Ecuadordurante-todo-el-año\#Sections-Temperature, accessed April 19, 2021.

[33] Kouperman, J., Determinación y mapeo de las áreas potencialmente incorporables al desarrollo sustentable, a partir de la implementación del plan hidráulico en la provincia de Santa Elena (Determination and mapping of areas potentially incorporable to sustainable development, based on the implementation of the hydraulic plan in the province of Santa Elena), Pontificia Universidad Católica Santiago del Ecuador, 2014.

[34] Herrera-Franco, G., et al., Geosites and georesources to foster geotourism in communities: Case study of the Santa Elena Peninsula Geopark Project in Ecuador. Sustainability, 12(11), p. 4484, 2020. https://doi.org/10.3390/su12114484

[35] Calderón, F. \& Ortega, E., Estrategias de marketing para fortalecer el posicionamiento de la cooperativa de producción minera El Tablazo $\mathrm{N}^{\circ} 1$, del cantón Santa Elena (Marketing strategies to strengthen the positioning of the mining production cooperative El Tablazo N ${ }^{\circ}$, Santa Elena canton), provincia de Santa Elena, año 2018, Universidad Estatal Península de Santa Elena, 2020.

[36] León-Valle, W., Linda, N.G., Valencia, A. \& Cedeño, J., La Pesca Artesanal un legado del saber ancestral, provincia de Santa Elena (Artesanal fishing a legacy of ancestral knowledge, province of Santa Elena). Revista de Investigaciones Sociales, 3(10), pp. 51-63, 2017.

[37] Proyecto Geoparque, Itinerario Educativo: Proyecto Geoparque Península Santa Elena (Educational Itinerary: Peninsula Santa Elena Geopark Project), 2019. https://proyectogeoparque.wixsite.com/peninsulasantaelena/post/itinerario-educativo-proyecto-geoparque-península-santa-elena (accessed May 23, 2021)

[38] Herrera, G. \& Alvarado, N., Geoparque Ancón-Santa Elena en el Contexto del Ordenamiento del Territorio (Ancón-Santa Elena Geopark in the Context of Territorial Planning), Libr. Actas del IV Congr. Int. Geol. y Minería Ambient. para el Ordenamiento Territ. y el Desarro., pp. 185-198, 2016. 
[39] Herrera, G. \& Montalván, F., Factores Geoambientales de los pozos petroleros y su incidencia en el desarrollo territorial en los cantones Salinas y La Libertad de la provincia de Santa Elena (Geo-environmental factors of oil wells and their impact on territorial development in the cantons of Salinas and La Libertad of the Santa Elena province), Proyectos UPSE, 2021.

[40] Garmendia, A., Salvador, A., Crespo, C. \& Garmendia, L., Evaluación de impacto ambiental (Environmental impact assessment), 1st ed., Pearson Educacion: Madrid, 2005.

[41] Herrera, K. \& Rocha, M., Estudio del impacto ambiental de los procesos de las industrias clasificadas por el CIIU (Categorización Internacional Industrial Uniforme) ubicadas en las parroquias Machachi y Aloag pertenecientes al cantón Mejía (Study of the environmental impact of the processes of the industries classified by the ISIC (International Uniform Industrial Categorization) located in the Machachi and Aloag parishes belonging to the Mejía canton), Universidad Politécnica Salesiana, 2015.

[42] Encinas, M.D. \& Gómez de Balugera, Z., Evaluación de Impacto Ambiental Aspectos Teóricos (Environmental Impact Assessment: Theoretical Aspects), Escuela Universitaria de Ingeniería de Vitoria-Gasteiz, 2011.

[43] Dall'agnol, C.M., de Magalhães, A.M.M., de M. Mano, G.C., Olschowsky, A., \& da Silva, F.P., A noção de tarefa nos grupos focais (The notion of task in focus groups). Revista gaúcha de enfermagem, 33(1), pp. 186-190, 2012. https://doi.org/10.1590/ S1983-14472012000100024

[44] Kinalski, D.D.F., de Paula, C.C., de M. Padoin, S.M., Neves, E.T., Kleinubing, R.E. $\&$ Cortes, L.F. Focus group on qualitative research: experience report. Revista Bras. Enfermagen, 70(2), pp. 424-429, 2017. https://doi.org/10.1590/0034-7167-2016-0091

[45] Herrera, G., Carrión, P. \& Briones, J., Geotourism potential in the context of the geopark project for the development of Santa Elena province, Ecuador. WIT Transactions on Ecology \& the Environment, Vol. 217, pp. 557-568, 2018. https://doi.org/10.2495/ SDP180481

[46] Mata-Perelló, J., Carrión, P., Molina, J. \& Villas-Boas, R., Geomining heritage as a tool to promote the social development of rural communities. Geoheritage, pp. 167-177, 2018.

[47] Franco, G.H., Mero, P.C., Carballo, F.M., Narváez, G.H., Bitar, J.B. \& Torrens, R.B., Strategies for the development of the value of the mining-industrial heritage of the Zaruma-Portovelo, Ecuador, in the context of a geopark project. International Journal of Energy Production \& Management, 5(1), pp. 48-59, 2020. https://doi.org/10.2495/ EQ-V5-N1-48-59

[48] Carrión Mero, P., Herrera Franco, G., Briones, J., Caldevilla, P., Domínguez-Cuesta, M. \& Berrezueta, E., Geotourism and local development based on geological and mining sites utilization, Zaruma-Portovelo, Ecuador. Geosciences, 8(6), p. 205, 2018. https:// doi.org/10.3390/geosciences8060205

[49] Herrera-Franco, G., Montalván-Burbano, N., Carrión-Mero, P., Apolo-Masache, B. \& Jaya-Montalvo, M., Research trends in geotourism: A bibliometric analysis using the Scopus database. Geosciences, 10(10), p. 379, 2020. https://doi.org/10.3390/geosciences 10100379

[50] Tomalá, M., Estudio técnico para la implementación de un sistema de tratamiento de suelos contaminados de hidrocarburos que minimizará el impacto ambiental de la empresa Asociación SMC. Pacifpetrol Inc. Ubicada en la parroquia Ancón, provincia de Santa Elena (Technical study for implementing a treatment system for hydrocarbon 
contaminated soils that will minimise the environmental impact of the SMC Association company), Universidad Estatal Península de Santa Elena, 2018.

[51] Botero, C.M., et al., Litter assessment on 99 Cuban beaches: A baseline to identify sources of pollution and impacts for tourism and recreation. Marine Pollution Bulletin, 118(1-2), pp. 437-441, 2017. https://doi.org/10.1016/j.marpolbul.2017.02.061

[52] Rodríguez Martínez, R., Torres Rodríguez, I., Suárez Melo, Y., García Fuentes, O. \& Beltrán González, J., Nivel de contaminación por hidrocarburos del petróleo en zonas costeras de Cuba (Level of oil pollution in coastal areas of Cuba). AquaDocs, pp. 1-10, 2021. 